\title{
A disposable amperometric ethanol biosensor based on screen-printed carbon electrodes mediated with ferricyanide-magnetic nanoparticle mixture
}

\author{
Min-Hung Liao ${ }^{\mathrm{a}}$, Jin-Chuan Guo ${ }^{\mathrm{b}}$, Wen-Chang Chen ${ }^{\mathrm{b}, *}$ \\ ${ }^{a}$ Department of Cosmetology Styling, Applied Science Technology Research Center, Transworld Institute of Technology, \\ Douliou, Yunlin 64063, Taiwan, ROC \\ ${ }^{\mathrm{b}}$ Department of Chemical Engineering, National Yunlin University of Science and Technology, 123, University Rd., Sec 3, \\ Douliou, Yunlin 64002, Taiwan, ROC
}

Available online 6 March 2006

\begin{abstract}
Magnetic $\mathrm{Fe}_{3} \mathrm{O}_{4}$ nanoparticles were prepared by co-precipitation method and used to develop a reagentless disposable amperometric ethanol $(\mathrm{EtOH})$ biosensor. The electrochemical characteristics of modified processes were analyzed by cyclic voltammetry $(\mathrm{CV})$ and chronoamperometry (CA). Results showed that the presence of $\mathrm{Fe}_{3} \mathrm{O}_{4}$ nanoparticles could enhance the peak currents of redox species. Moreover, the alcohol biosensor exhibited an excellent sensitivity and fast response time for EtOH with a wide linear response range from 1.0 to $9.0 \mathrm{mM}$.
\end{abstract}

(C) 2006 Published by Elsevier B.V.

Keywords: $\mathrm{Fe}_{3} \mathrm{O}_{4}$ nanoparticles; EtOH biosensor; Screen-printed carbon electrodes (SPCEs)

\section{Introduction}

Sensitive and selective amperometric biosensors are required for $\mathrm{EtOH}$ determination in fermentation and distillation processes, as well as in the clinical diagnostic analyses $[1,2]$. The amperometric EtOH biosensing response is based on the oxidation of NADH, which was generated in the enzymatic reaction of ethanol with $\mathrm{NAD}^{+} /$YADH system, by a mediator (e.g. ferricyanide, Ferri) [2-5]. The overall electrochemically biosensing scheme is as shown in Fig. 1. However, the YADH-based EtOH biosensors suffer rapid activity loss [4-6] with the dependence on a soluble cofactor $\left(\mathrm{NAD}^{+} / \mathrm{NADH}\right)$ [7], and also a high overpotential for the direct oxidation of NADH at a bare electrode surface $[1,3,5]$.

Since nano-sized magnetic bioconjugated materials could potentially result in many unique properties such as large surface area, higher bioactivity, excellent con-

\footnotetext{
*Corresponding author. Tel.: + $88655342601 \times 4621$; fax: +88655312071 .

E-mail address: chenwc@yuntech.edu.tw (W.-C. Chen).
}

formation stability, and better contact between biocatalyst and its substrate [8,9], there are growing interests in their applications for construction of biosensor devices.

In this study, magnetite $\left(\mathrm{Fe}_{3} \mathrm{O}_{4}\right)$ nanoparticles were prepared by co-precipitation method and a reagentless disposable amperometric biosensor, constructed by simple surface coatings of yeast $\mathrm{YADH}, \mathrm{NAD}^{+}$cofactor and

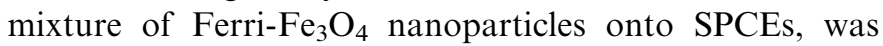
developed for ethanol monitoring. The modified processes of the SPCEs and the related electrochemical characteristics were analyzed by $\mathrm{CV}$. In addition, the optimal YADH loading was also evaluated by CA measurements.

\section{Experimental}

YADH from baker's yeast (EC 1.1.1.1, $450 \mathrm{U} \mathrm{mg}^{-1}$ solid) and $\beta$-NAD ${ }^{+}$were purchased from Sigma. Ferricyanide (Ferri) was obtained from Merck. All other chemicals were the analytic grade reagents and used without further purification.

$\mathrm{CV}$ and CA measurements were performed with Model 440 Electrochemical Workstation (CH Instruments, USA). 


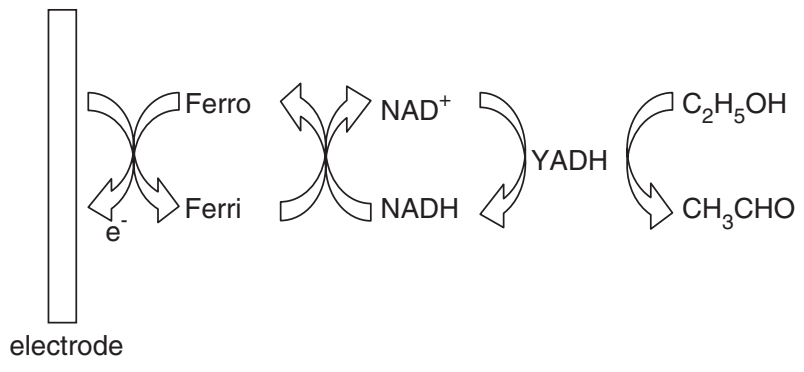

Fig. 1. $\mathrm{NAD}^{+}$-YADH/Ferri-based ethanol-biosensing mechanism.

All measurements were performed at room temperature. The size and morphology of the $\mathrm{Fe}_{3} \mathrm{O}_{4}$ nanoparticles were observed by TEM (JEOL model JEM-2010 at $200 \mathrm{kV}$ ). XRD measurement was performed on an X-ray diffractometer (MAC Sience/M 21 X, Japan) using $\mathrm{CuK}_{\alpha}$ radiation $(\lambda=0.1542 \mathrm{~nm})$. Disposable SPCEs were supplied by Apex Bio-technol. Corp.

Magnetic $\mathrm{Fe}_{3} \mathrm{O}_{4}$ nanoparticles were prepared by coprecipitation method according to the procedure described by Liao and Chen [6]. In total, $60 \mathrm{mg}$ of $\mathrm{Fe}_{3} \mathrm{O}_{4}$ nanoparticles were dispersed in $5 \mathrm{ml}$ phosphate buffer solution (PBS, 0.1 M, pH 8.8) containing $0.1 \mathrm{M}$ Ferri, and then the dispersed solution was sonicated for $1 \mathrm{~h}$. Ten microliters of $\mathrm{Ferri}^{-} \mathrm{Fe}_{3} \mathrm{O}_{4}$ solution was dropped onto SPCEs and dried at $50^{\circ} \mathrm{C}$ for $15 \mathrm{~min}$. Eight $\mathrm{mg}$ of YADH and $8 \mathrm{mg}$ of $\mathrm{NAD}^{+}$were dissolved in $4 \mathrm{ml}$ of PBS $\left([\mathrm{YADH}]=2 \mathrm{mg} \mathrm{ml}^{-1},\left[\mathrm{NAD}^{+}\right]=3 \mathrm{mM}\right)$. Ten microliters of $\mathrm{YADH} / \mathrm{NAD}^{+}$solution was dropped onto Ferri-Fe $\mathrm{O}_{4}$ SPCEs and dried at $30^{\circ} \mathrm{C}$. The disposable NAD ${ }^{+}-\mathrm{YADH} /$ Ferri- $\mathrm{Fe}_{3} \mathrm{O}_{4}$ deposited SPCEs were ready to use.

\section{Results and discussion}

The $\mathrm{Fe}_{3} \mathrm{O}_{4}$ nanoparticles synthesized in this study were essentially very fine and monodisperse with a mean diameter of ca. $9.8 \mathrm{~nm}$ from TEM image (not shown). In addition, six characteristic peaks for $\mathrm{Fe}_{3} \mathrm{O}_{4}(2 \theta=30.72$, $35.94^{\circ}, 43.74^{\circ}, 54.12^{\circ}, 57.54^{\circ}$ and $63.20^{\circ}$ ) were observed in the XRD patterns for the $\mathrm{Fe}_{3} \mathrm{O}_{4}$ nanoparticles (data not shown). From these diffraction data, it can be inferred that a spinel structure $\mathrm{Fe}_{3} \mathrm{O}_{4}$ has been synthesized [6].

$\mathrm{CV}$ is a simple and easy mean to show the changes of electrode behaviour in the modification process, because the electron transfer between the solution species and the electrode must occur by tunneling through either the barrier or the defects in the barrier. Fig. 2 shows the cyclic voltammograms of the modified process of Ferri (curve a), $\mathrm{NAD}^{+}-\mathrm{YADH} /$ Ferri (curve b), Ferri- $\mathrm{Fe}_{3} \mathrm{O}_{4}$ (curve c) and $\mathrm{NAD}^{+}-\mathrm{YADH} /$ Ferri- $\mathrm{Fe}_{3} \mathrm{O}_{4}$ (curve d) deposited SPCEs, respectively. It could be found that the peak currents of the curves (b) and (d) were decreased comparing with curves (a) and (c), respectively. This may originate from the insulating enzyme protein layer on the electrode that retards the electron transfer between redox probe and electrode surface. After $\mathrm{Fe}_{3} \mathrm{O}_{4}$ nanoparticles being deposited on the SPCEs, the peak currents were greatly increased. It might be suggested that the $\mathrm{Fe}_{3} \mathrm{O}_{4}$ nanoparticles could provide a favorable micro-environment for the enzyme to directly transfer electrons with electrodes [10].

CA measurements were examined with YADH loading on the SPCEs as a parameter. Amount of YADH loading was varied in the range from 0.002 to $0.050 \mathrm{mg}$ solid. The response current of the modified electrode was significantly dependent on the amount of enzyme loaded on the SPCEs, as shown in Fig. 3. An increase in the response current was observed up to $0.020 \mathrm{mg}$. Therefore, the loaded enzyme in further experiments was selected with $0.020 \mathrm{mg}$ YADH for each SPCEs-test strip.

The $\mathrm{NAD}^{+}-\mathrm{YADH} /$ Ferri- $\mathrm{Fe}_{3} \mathrm{O}_{4}$-based biosensors showed an excellent sensitivity for ethanol in a wide linear response range (Fig. 4). The calibration curve was obtained from 1 to $9.0 \mathrm{mM}$ of ethanol in $0.1 \mathrm{M}$ PBS at $\mathrm{pH} 8.8$ and

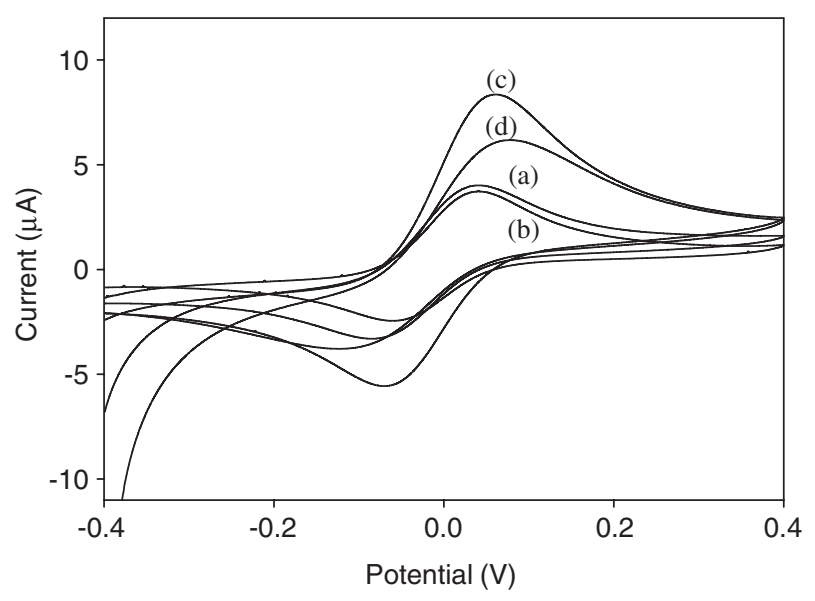

Fig. 2. Cyclic voltammograms of (a) Ferri, (b) $\mathrm{NAD}^{+}-\mathrm{YADH} /$ Ferri, (c) Ferri- $\mathrm{Fe}_{3} \mathrm{O}_{4}$ and (d) $\mathrm{NAD}^{+}-\mathrm{YADH} / \mathrm{Ferri}_{-} \mathrm{Fe}_{3} \mathrm{O}_{4}$ deposited SPCEs, respectively, in PBS (0.1 M, pH 8.8). Scan rate: $10 \mathrm{mV} \mathrm{s}^{-1}$.

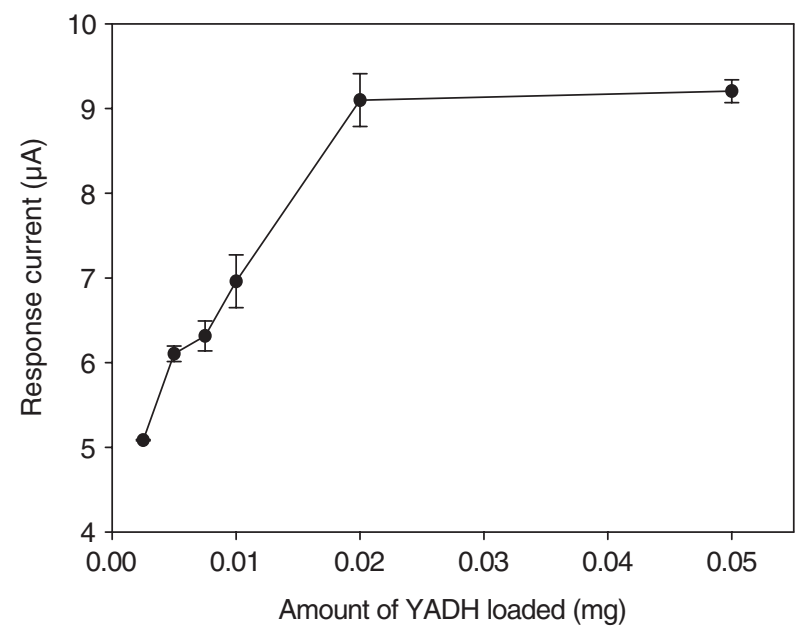

Fig. 3. Influence of the amount of YADH loaded on the response current of $\mathrm{NAD}^{+}-\mathrm{YADH} /$ Ferri- $\mathrm{Fe}_{3} \mathrm{O}_{4}$ deposited SPCEs. Applied potential: $0.2 \mathrm{~V}$. 


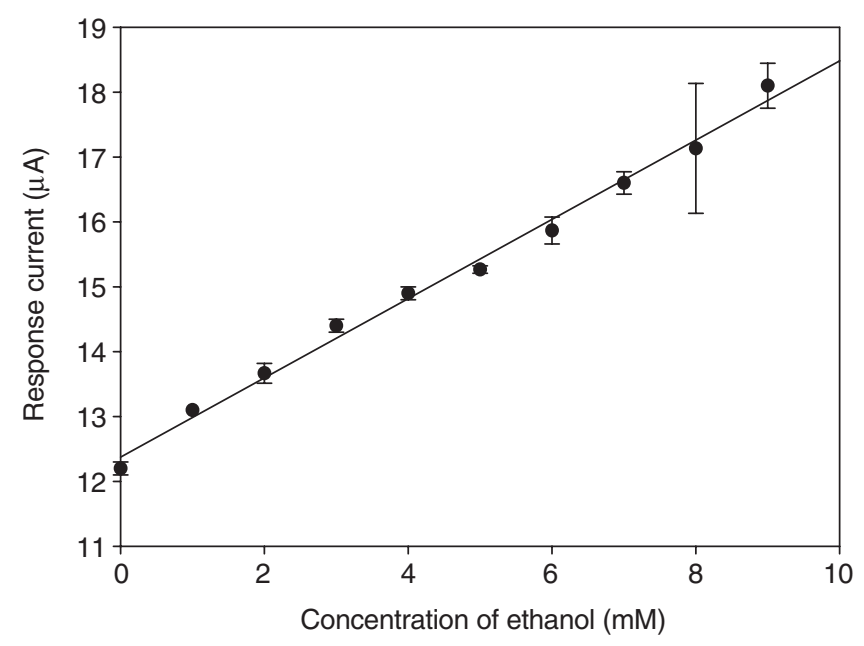

Fig. 4. Calibration curve for ethanol obtained from $\mathrm{CVs}$ by $\mathrm{NAD}^{+}-$ $\mathrm{YADH} / \mathrm{Ferri}-\mathrm{Fe}_{3} \mathrm{O}_{4}$-based biosensors.

the following linear equation is obtained: Response current $(\mu \mathrm{A})=0.61\left[\right.$ ethanol] $+12.38, R^{2}=0.9929$.

\section{Conclusions}

$\mathrm{Fe}_{3} \mathrm{O}_{4}$ nanoparticles were successfully prepared by coprecipitation method and they were used to develop a disposable, reagentless biosensor for alcohol determination in a simple and effective way. It was found that using $\mathrm{Fe}_{3} \mathrm{O}_{4}$-deposited SPCEs, the response currents of redox species by $\mathrm{CV}$ measurement could be enhanced. Also, the $\mathrm{NAD}^{+}{ }_{-} \mathrm{YADH} / \mathrm{Ferri}-\mathrm{Fe}_{3} \mathrm{O}_{4}$-based biosensor showed an excellent sensitivity $\left(0.61 \mu \mathrm{AmM}^{-1}\right)$ and fast response time $(20 \mathrm{~s})$ for $\mathrm{EtOH}$ in $0.1 \mathrm{M}$ PBS (pH 8.8) with a wide linear response range from 1.0 to $9.0 \mathrm{mM}$.

\section{References}

[1] C.-X. Cai, K.-H. Xue, Y.-M. Zhou, H. Yang, Talanta 44 (1997) 339.

[2] M. Niculescu, T. Erichsen, V. Sukharev, Z. Kerenyi, E. Csoregi, W. Schuhmann, Anal. Chim. Acta 463 (2002) 39.

[3] M.J.L. Castanon, A.J.M. Ordieres, P.T. Blanco, Biosens. Bioelectron. 12 (1997) 511.

[4] N. Reshetilov, J.A. Trotsenko, N.O. Morozova, P.V. Iliasov, V.V. Ashin, Process Biochem. 36 (2001) 1015.

[5] S. Santos, R.S. Freire, L.T. Kubota, J. Electroanal. Chem. 547 (2003) 135.

[6] M.-H. Liao, D.-H. Chen, Biotechnol. Lett. 23 (2001) 1723.

[7] E. Dominguez, H.L. Lan, Y. Okamoto, P.D. Hale, T.A. Skotheim, L. Gorton, B. Hahn-Hagerdal, Biosens. Bioelectron. 8 (1993) 229.

[8] E. Katz, I. Willner, J. Wang, Electroanalysis 16 (2004) 19.

[9] L.M. Rossi, A.D. Quach, Z. Rosenzweig. Anal. Bioanal. Chem. 380 (2004) 606.

[10] D. Cao, P. He, N. Hu, Analyst 128 (2003) 1268. 